

ISSN: 1916-7822 A Journal of Spread Corporation

Volume 1 No. $1 *$ Pages $126-140 *$ October 2010

\title{
ACADEMIC AND SOCIAL CHALLENGES FACING STUDENTS WITH DEVELOPMENTAL AND LEARNING DISABILITIES IN HIGHER INSTITUTIONS: IMPLICATIONS TO AFRICAN COLLEGES AND UNIVERSITIES
}

\author{
Williams Emeka Obiozor, Ed.D. \\ Bloomsburg University of PA \\ Obiozor66@hotmail.com,wobiozor@bloomu.edu \\ Onu, V. C., PhD. \\ University of Nigeria, Nsukka. \\ Ifeanyi Ugwoegbu, PhD. \\ Nnamdi Azikiwe University, Nigeria
}

\begin{abstract}
.
African societies have much to learn from the exemplary programs and projects on disabilities, adult literacy and special education provisions in developed societies, like the United States, where effective legislations, curriculum and support services are provided at all levels for individuals with disabilities. This paper discusses the academic and social challenges facing students with developmental and learning disabilities in higher institutions; including available services in institutions of higher learning for such individuals-something that is yet to be introduced or effectively conducted in most African nations unlike in the United States. This paper noted the challenges which developmental and learning disabilities pose to students in general; as well as recognize the potentials, talents, and individual abilities of such students in contemporary institutions of higher learning which could be applicable to African universities and colleges. In this regards, recommendations on understanding student developmental and learning disabilities; application of universal design for learning (UDL), and the institutional roles needed to ensure that such students cope in class and achieve success on campus, were provided.
\end{abstract}




\section{Academic and Social Challenges Facing Students with Developmental and Learning Disabilities in Higher Institutions: Implications for African Colleges and Universities}

\section{INTRODUCTION}

\section{What do People with Disabilities Want?}

We all want the same basic things out of life: a decent and comfortable place to call 'home', something meaningful to do during the day, some close friends with whom to share the good times and from whom we receive support in difficult times, and the opportunity to make our own decisions about things that will affect our personal lives. People with disabilities want these same basic things and are increasingly speaking up for themselves about what they want. And staff, family and State agency professionals are beginning to really listen.

Excerpted from "Home, Sweet Home" by Susan L. Babin, IMPACT: Feature Issue on Supported Living (1995), published by the Institute on Community Integration.

\section{The Student Disability Challenge}

Students with developmental and learning disabilities are expected to benefit from comprehensive long-term services which empower them to be more active, productive, and independent, which equally benefits their families and communities. This, notwithstanding, today's student with developmental and learning disability is confronted with several challenges in life, especially in the postsecondary settings where attending two-year college or university is an option for the exceptional individual. Aside from coping with the trauma of a disability which may be mild, moderate, severe or profound, the student may find it difficult to access and afford several facilities and services while attending a higher institution. The absence of significant facilities and services could severely limit independence, geographical mobility, and employment opportunities upon graduation, i.e. where such student did not drop out.

In the United States, the government legislation on supporting people with disabilities, Americans with Disabilities Act (ADA) (1990) clearly defines disability by providing three general guidelines, all of which are necessary; (1) the presence of a physical, cognitive, intellectual, or psychiatric condition, or a combination of conditions; (2) pervasive impairment in social and occupational functioning; and (3) individuals with these impairments are the target of prejudice, discrimination, stigma, and reduced opportunities. In this regard, Smart (2009), argued that it can be seen that disability is a combination of the condition, limitations in functioning, and societal prejudice and discrimination. Hallahan \& Kauffman (2003; 5) defined a disability as "an inability to do something, the lack of a specific capacity". A disability could be mild, moderate, profound or severe. In addition to this term is handicap, described as "a disadvantage that is imposed on an individual".

While Hallahan \& Kauffman argued that a disability may or may not be perceived as a handicap, but depending on the circumstances; they explained their position with an illustration, thus: the inability to walk is not a handicap in learning to read, but it can be a handicap in getting into the stands at a ball game. Furthermore, sometimes handicaps are needlessly imposed on people with disabilities. Hallahan \& Kauffman gave an example, thus: a student who cannot write with a pen but can use a typewriter or word processor would be needlessly handicapped without such equipment. 
For the public schools system, the government of the United States' legislation and guiding principles were developed to empower and provide support services to individuals with disabilities: Example, the Individuals with Disabilities Education Act (IDEA) 1990, which ushered the rights for people with disabilities and their families; and the Americans with Disabilities Act (ADA) - Federal law requiring accommodations for people with disabilities in the community and work place. Instructors in public institutions adhere to these regulations, with the belief that all individuals can learn and be given equal educational opportunities in the inclusion setting. In support of the legislations, Berry (2009) argued that all persons are capable of growth and development, hence, should be given opportunities to excel. Students with developmental and learning disabilities receive accommodation(s) based on documentation of their disability. Such students requesting accommodation(s) are responsible for initiating services by providing the College/University Disability Services Office established in all American institutions of higher learning for the purpose of handling appropriate disability support service documentation which should be prepared by a physician, psychologist, and psychiatrist, etc. The documentation should include information about how the student's disability will affect his/her ability to equally access the educational opportunities, programs, and activities at college/university (Obiozor, 2009).

In American higher institutions, the instructors and professors are expected to recognize the documentation on student disability and provide the necessary support required by the student in the classroom during instruction and assessments/tests. Some of the exceptional students can handle their disability whether it is cognitive, physical, communication, social, emotional, or adaptive skills; or a diagnosed learning, developmental, physical or medical condition while others may need as much assistance as possible (Obiozor, 2009).

\section{Developmental Disability Challenge}

The Institute on Community Integration (ICI) at the University of Minnesota reported that over 6 million individuals in the United States have developmental disabilities. Graduate and undergraduate students with such disabilities are included in this population, and they all require attention and support services - academic and social, from the instructors and professors. The Institute gave detailed account of the developmental disabilities, thus:

A developmental disability, according to the Developmental Disabilities Assistance and Bill of Rights Act, is defined as a severe, chronic disability which originated at birth or during childhood; is expected to continue indefinitely, and substantially restricts the individuals functioning in several major life activities. More specifically,

a developmental disability is a severe, chronic disability which is attributable to a mental or physical impairment or a combination of mental and physical impairments; is manifested before the person attains age 22; results in substantial functional limitations in three or more of the following areas of major life activity: self-care, receptive and expressive language, learning, mobility, self-direction, capacity for independent living, and economic self-sufficiency; reflects the person's need for a combination and sequence of special, interdisciplinary, or generic care, treatment, or other services which are of lifelong or extended duration and are individually planned and coordinated; except that such term when applied to infants and young children means individuals from birth to age five, inclusive, who have substantial developmental delay or specific congenital or acquired conditions with a high probability of resulting in developmental disabilities if services are not provided (ICI, 2010).

Examples of developmental disabilities include: 


\section{Autism Spectrum Disorders}

Autism is considered to be a pervasive developmental disorder (PDD) - besides autism, other PDD include Asperger's syndrome, Rett syndrome, and Childhood Disintegrative Disorder (CDD) This is a severe disability which manifests in the nature of the individual language and by their personal and social behavior (Westling \& Fox, 2004). In other words, Autism as a developmental disorder, significantly affect verbal and nonverbal communication and social interaction of the student (Anderson, 2006).

Autism adversely affects a student's educational performance and social activity at home, school, and community setting as well. Other characteristics often associated with autism are engagement in repetitive activities and stereotyped movements, resistance to environmental change or change in daily routines, and unusual responses to sensory experiences. Students with autism vary widely in abilities, intelligence, and behaviors (Westling \& Fox (2004); Hallahan \& Kauffman (2003); Smart (2009); Heward (2009).

\section{Behavior disorder}

This is a condition with one or more behavioral characteristics that are:

1. exhibited at either a much higher or much lower rate than is appropriate for one's age;

2. documented as occurring over an extended period of time in different environmental settings within the school and home or community; and

3. interfering consistently with the student's educational performance. This interference with educational performance shall not be a result of intellectual, sensory, cultural, or health factors that have not received appropriate attention (Anderson, 2006; Heward, 2009).

\section{Head/Brain injury}

An acquired injury to the brain caused by an external physical force, resulting in total or partial functional disability or psychosocial impairment, or both that adversely affects an individual's educational performance. The term applies to open or closed head injuries resulting in impairments in one or more areas, such as cognition; language; memory; attention; reasoning; abstract thinking; judgment; problem solving; sensory, perceptual and motor abilities; psychosocial behavior; physical functions; information processing; and speech. The term does not apply to brain injuries that are congenital or degenerative or brain injuries induced by birth trauma (Anderson, 2006).

\section{Cerebral palsy}

This is a motor impairment caused by brain damage, which is usually acquired during the prenatal period or during the birth process (Heward, 2009). Symptoms of cerebral palsy can be as simple as having difficulty with fine motor tasks like writing or using scissors, or as profound as being unable to maintain balance or walk. Severely afflicted patients may have involuntary movements, such as uncontrollable hand motions and drooling. Others suffer from associated medical disorders, such as seizures and mental retardation (MediZine, 2010). Cerebral palsy is neither curable nor progressive.

\section{Down syndrome}

This is a chromosomal anomaly that often causes moderate-to-severe mental retardation, along with certain physical characteristics such as large tongue, heart problems, poor muscle tone, and a broad, flat bridge of the nose (Heward, 2009).

\section{Fetal alcohol syndrome (FAS)}

This term, according to Heward (2009) refers to a condition found in infants of alcoholic mothers; can involve low birth weight, developmental delay, and cardiac, limb, and other 
physical defects. Caused by excessive alcohol use during pregnancy; often produces serious physical defects and developmental delays; diagnosed when the child has two or more craniofacial malformation $\mathrm{s}$ and growth is below the $10^{\text {th }}$ percentile for height and weight. FAS is one of the leading causes of cognitive delays, language delays and mental retardation.

\section{Mental/Intellectual Disability}

This disability is a significantly subaverage general intellectual functioning existing concurrently with deficits in adaptive behavior and manifested during the developmental period that adversely affects an individual's educational performance (Anderson, 2006). Mental disability limits a student's conceptual, social and adaptive skills, and the disability originates before age 18 (Heward, 2009; AAIDD, 2007).

\section{Spina Bifida}

Heward (2009) defined Spina Bafida as a congenital malformation of the spine in which the vertebrae that normally protect the spine do not develop fully; may involve loss of sensation and severe muscle weakness in the lower part of the body.

\section{Learning Disabilities}

Heward (2009); Hallahan \& Kauffman (2003) \& Anderson (2006) gave explained well the definition of learning disabilities: A disorder in one or more of the basic psychological processes involved in understanding or in using language, spoken or written, that may manifest itself in an imperfect ability to listen, think, speak, read, write, spell, or to do mathematical calculations, including conditions such as perceptual disabilities, brain injury, minimal brain dysfunction, dyslexia, and developmental aphasia. The term does not apply to individuals who have learning problems that are primarily the result of physical or mental disabilities, behavioral disorder, or environmental, cultural, or economic disadvantage.

According to the data from the Beginning Postsecondary Student survey: Almost half (46 percent) of first-time students who left their initial institution by the end of the first year never came back to postsecondary education (Studentretention.org, 2005). Some of the reasons could be attributed to the disabilities discussed in this paper, and related problems of finance, relationships, study skills and poor academic advisement, faced by these students in their freshman year which cause them to drop out. It is pertinent to note that students with developmental and learning disabilities go on academic probation or even drop out of college when professors or instructors show no concern on their academic plight or lack of support services to deal with academic and social issues, whether they are personal or ecological. The students should discuss the academic problems which they encounter daily in their classrooms or social relationship needs on campus, as well as identify possible strategies to solve them, by taking advantage of the available abundant support services on campus which promote meaningful teaching-learning process and student achievement.

\section{Avoiding Assistance from the College/University}

A major reason for students with developmental and learning disabilities not reporting their disabilities to the university authorities could be to avoid labeling or stigmatization, but these students fail to realize that with the support and assistance from the university, it becomes easy to navigate their academic activities on campus (Obiozor, 2009). Based on the author's research and personal classroom experiences in the college and university settings in America; there are other factors which compel students with developmental and learning disabilities to leave the classroom or campus as found in the research literature. This includes family issues; poor academic preparedness, for example, lack of time management, organization and study 
skills: reading, writing, math and research activities; unfavorable classroom or campus climate; inadequate commitment to educational goals and the institution especially as regards the role of the university vision and mission in meeting the student academic and social goals; issue of social and academic integration of students with developmental and learning disabilities (How committed are the University, Student Government Board, and Student Center Programs to attaining the goals?); accessing financial aid by the students from low income and minority groups.

There is no doubt that the faculty and administrative staff of every higher institution is equipped with innovative tools and resources to conduct student-centered instruction and provide support services. They possess different expertise in a variety of areas, with strong teaching background and professional service profiles to face the challenges in the classroom. This is evident from their rigorous years of training and research in different fields.

Furthermore, these instructors, lecturers or professors possesses skills in large class instruction, use of classroom technology, knowledge of research methodology, planning and implementation of service learning projects, course-embedded assessment, engaging students in learning, as well as interpersonal skills which benefit and enhances students' learning, research and academic achievement. Although American colleges and universities utilize the above mentioned teaching-learning facilities, they still experience exceptional student attrition. This paper examined the reasons behind the student departure from the classroom and campus environment, aside from family or financial problems.

It is pertinent to note that several students with developmental and learning disabilities have behavioral issues and pressing academic problems - some are displayed in the classroom, others could be noticed when they fill student evaluation forms at the end of the semester. Among the signs in the classroom which could be a signal to the instructor or professor concerning student academic and social issues could be as follows: absenteeism, lateness to class, drooling and sneezing uncontrollably, uncompleted class tasks and assignments, yell out loud in class, sending texts with their phones to friends during class, rudeness towards the teacher, display of anxiety during quizzes and test-taking problems, and low test scores. All these problems in the classroom could result in students with learning and developmental disabilities withdrawing from the class or drop out of the institution.

\section{Using Effective Teaching Methods to Motivate and Promote Active Learning of Students with Learning and Developmental Disabilities}

Although higher institutions aspire to provide effective instructional curriculum and programs for students with learning and developmental disabilities, for them to learn better in the campus environment, but some of these institutions are not doing enough to prepare instructors and professors to meet their academic and non-academic needs. Kelly (2010) identified some of the more common learning disabilities to include dyslexia, expressive language disorder, reading processing disability, and attention deficit disorder. Ideally, the students will self-identify and contact the institution's disability services office so the instructor will know what accommodations are required, but not all students are forthcoming about letting others know about their learning disabilities, says Mary Beth Crum, an online instructor at the American University of Wisconsin.

Furthermore, in her research on the issue of addressing these disabilities in the classroom, according to Kelly (2010); Crum asked departments of disabilities how instructors could help students with learning disabilities. Their response: open and constant communication, 
compassion, a willingness to bend the rules to accommodate students, and one-on-one instruction. Since this is the case in some institutions, the classroom instructors should device effective teaching strategies to reach out to every student in the classroom, especially for those who have been able to disclose their learning and developmental disability issues. Instructors of students with learning and developmental disabilities should endeavor to adopt the following strategies in the classroom suggested by Duquette (2006); break concepts into smaller chunks, and talk slowly in order to give clear explanations on the content; utilize hands-on activities \& concrete materials; repeat concepts and procedures, and break task down into smaller components using task analysis. Other methods include, giving frequent breaks; demonstrate what has to be done instead of orally, and teach shorter lessons with active student involvement and guided practice; use prompts, cues, praise and positive reinforcement

The essence of communicating with the students with exceptionalities in this regard cannot be overemphasized. One aspect of communication that some instructors overlook is feedback on assignments, stressed Kelly (2010) adding that Crum in her research, opined on the need to make comments on every paragraph of submitted assignments by the students, because it's a great opportunity to maintain that communication with students. This is a technique she applies across the board, and it benefits students with and without learning disabilities. The author further opined that special accommodations for students with learning disabilities can include extending deadlines, working with the disabilities services office to help students get access to assistive software, or working individually with the student, and matching the struggling student with a professor that has a lot of compassion.

\section{Typical Institutional Support Service Centers in Higher Institutions}

This lack of disclosure makes supporting students with learning disabilities difficult for online instructors. Further complicating the issue is that under FERPA instructors cannot make the determination or question the student as to whether they have a learning disability. Instructors can raise concerns about a student's performance (chronic late assignments, excessive errors in discussion board posts, irrelevant or inappropriate answer to questions that seem to indicate a lack of understanding, etc.) and recommend that the student talk with his or her advisor, at which point the student may make his or her learning disabilities known.

Every American institution of higher learning has great student and faculty support model for everyone on campus. Students with developmental and learning disabilities take advantage of these free support services to assist them in solving their learning problems, other academic and social needs. The same kind of support programs and projects are available in different American institutions of higher learning, and the author implores all students and faculty to access them for their social and academic success in the classroom, and campus environment. Examples of support service centers that could be found in different American institutions are described on the website of the Bloomsburg University, a foremost teacher training and education center in Northern Pennsylvania: http://www.bloomu.edu/academic/services.php. These centers/offices are as follows;

Office of Accommodative Services for Students with Disabilities: This kind of office offers a wide range of activities designed to support and enhance the performance of students with disabilities. Services include, but are not limited to: provision of accommodative testing, note takers, scribes, interpreters, readers, auxiliary aides, adaptive equipment, and liaison between students and faculty in classroom accommodations. The office also serves as an

AJOTE Vol. 1. No. 1, 126-140 
advocate for the student in issues of accommodation beyond the classroom, and acts as a liaison with other campus offices.

Act 101/Educational Opportunity Program: In this special program, students receive special support in instruction, academic advising, counseling, tutoring, financial aid advising and other assistance as necessary in maximizing their opportunity for success in college. Students admitted through this program take diagnostic tests to ensure correct placement in classes and most new students participate in a summer program prior to the first semester of their attendance where special assistance in tutoring and counseling is given to address specific academic, financial, and social needs.

Developmental Instruction: This program provides academic advisement, instruction, tutoring, and other support to assist students in their academic endeavors and to maximize their potential for success in college, especially those students that enter through Act 101 and EOP. Success in college is defined as achievement of academic good standing and graduation. Services include credit and developmental courses in reading, writing, and mathematics; developmental laboratories, professional tutorial assistance, and advisement. The department supports the university's retention effort, especially among the high-risk groups and the ethnic minority groups at the university.

International Education Office: This type of office advises and counsels international students on personal, intercultural, and academic matters while they are completing their academic programs on campus; prepares college students for student teaching, internships, and employment opportunities abroad; assists international students with immigration, housing, health insurance, and on and off campus employment; facilitates intercultural exchange through cultural activities and events organized by various international clubs and associations on campus; and clarifies expectations of international students between their homes and American culture through various cross-cultural, community outreach activities.

Office of Diversity and Retention: This office develops, coordinates and implements programs and services to assist students of color in achieving their educational goals. The office engages students in the educational process to enhance their opportunity to succeed.

University Tutorial Services: This office offers assistance designed to support and enhances the performance of university students. Peer tutoring is available upon request in a variety of courses and is provided by students who have distinguished themselves by superior academic performance. Any student requesting tutorial assistance need only complete a brief application in order to apply for the free service.

Office of Multicultural Affairs: The Office of Multicultural Affairs is established in higher institutions to support the social and academic development of multicultural students through specific academic support services, and to educate the entire academic community through sponsored or co-sponsored programs.

Campus Child Center: A well-organized institution must have a Campus Child Center which provides day care services for children of college students, faculty, staff, alumni and community children who are eligible for child center services. Service hours are usually from morning to evening. Children served are from ages six months to 12 years with flexible scheduling options for such students who are parents.

Student Career/Employment Center: Institutions of higher learning have Student Career or Employment Centers which employs approximately part-time student employees in a variety of positions throughout the campus. Student employees on campus enjoy flexible schedules and convenient locations to work on campus. They receive good pay, the development of leadership

AJOTE Vol. 1. No. 1, 126 - 140 
skills, team work/team building skill development, technical skills, human relations, decisionmaking and problem solving.

Center for Counseling and Human Development: Different individuals have difficulty adjusting to the challenges of college life. It's not unusual to feel anxious or uneasy about course work, relationships, or the day-to-day pressures of the university. The Center for Counseling and Human Development at any given campus is a place where you can go to talk out your problems or just get things off your chest. The process of counseling may be challenging at times, but it can also lead to very positive outcomes. And your visit is confidential.

\section{Implications to African Colleges and Universities}

African schools, whether in the primary, secondary, tertiary, or higher institutional settings are challenged by global education trends. Mbiti (1989: 221) points to the African educational system as a serious threat to the African society. Grol and Kenosi (2000) argued that, in traditional society boys and girl were prepared for life by being informed about marriage, sex and family life. No attention is paid to these aspects of life within the modern educational system; 'vivisection of a frog seems to carry more importance than preparation for community life'. Nevertheless, post-colonial governments still use this modern, western-based educational system for a set of reasons (Kisanji, 1996, 63-64); Grol and Kenosi (2000):

- Political leaders are successful products of this system.

- The tendency to think schooling leads to economic growth.

- Education is free for all citizens as far as feasible; priority is with the academic well performing pupils.

- The curriculum concentrates on academics only, striving to get the students paid jobs in government or business through secondary and tertiary education.

In a provocative way Mihyo (1995) suggests another educational system could lead to another society making policymakers dependent on subordinates, implicating a loss of power and prestige. Also, lack of funds could be among the reasons why African governments neglected or abandoned educational innovations. As a result, a large part of the African education is not only western-based, but also outdated. As long as this happens, argues Mutasa $(1994,70)$ the school curriculum can never play a prominent role in the development of the African human culture.

As special education and adult education scholars, we have been privileged to visit several institutions of higher learning in different parts of America, United Kingdom and some African nations (like Nigeria, The Gambia, Senegal, Sierra Leone, etc.), assessed the resources and facilities provided to students with disabilities or exceptionalities to promote academic achievement; there are strong contrasts to the practice in African higher institutions. The lack of effectiveness of legislation and policy on disability issues and special education programs are affecting the development of the African institutions. Many African countries develop splendid policy plans to stimulate the teaching of students but fail to implement them, laments Grol and Kenosi (2000). There are either poor or non-existent disability support facilities for students with disabilities in African colleges and universities. The lack of facilities affects the enrollment, retention and graduation of skilled individuals with disabilities in African institutions.

Furthermore, the African educational system lack adequate funding, training facilities, resources and effective special needs curriculum; thus, most scholars, professors and instructors find it difficult to assist students with disabilities in attaining academic and social successes on 
campus. The only feasible programs could be found in few institutions where most African countries south of the Sahara use the 'Resource Room' model according to Charema and Peresuh (1996.) This model is commonly used in the United States but not all African institution can afford such facilities.

Therefore, the author is using this medium to advocate for governments in Africa to enact legislations to support the adequate funding of colleges and universities in Africa, to establish exceptional needs offices on every campus or even an institute for disability training, information processing and dissemination, scientific research, and development of teaching/learning methods for students with disabilities/exceptionalities. The resource office or institute should have the kind of facilities and services provided by the Bloomsburg University offices for exceptional students (as highlighted in this paper). Such facilities should offer and provide resource services, like;

- Training of instructors and professors on how to recognize/assist/teach students with special needs in higher institutions.

- Community awareness campaigns on how to prevent disabilities, deal misconceptions/cope with disabilities, and how to support students/people with disabilities on campus.

- Therapy and counseling services for students and their parents, among other academic support services.

- Conduct research and disseminate information on latest diagnosis and treatment of different disabilities

- Facilitate assistive technology devices for individuals with disabilities.

\section{Recommendations for Students and Instructors (Obiozor, 2009)}

a. The governments should provide funds, resources and enact effective legislation and policy on disability issues and special education programs which would help the development of the African students and higher institutions.

b. Instructors should be alert and attentive to student behaviors in classrooms - comments, giggles, questions, facial expressions. This could be a sign of some social/learning problems or disability; address them immediately after class. As for the exceptional student, you can access assistance from the appropriate offices on campus so that you can receive uninterrupted education and succeed in class. Be respectful and concentrate in your class demands and responsibilities because you are accountable for your actions.

c. Make strong emphasis on interpersonal communication: Establish friendly but professional relations with your teachers and classmates - when you seem to be faced with issues of punctuality and regular attendance, talk with your teacher or counselor on campus; take teacher suggestions for counseling at any time you feel there is a need. Talk about your disability, and how you can be assisted to overcome them in class (where possible) especially if you keep failing your quizzes and tests; adhere to your teacher's demand for active participation in class, ask questions when confused, seek clarifications on assignments in order to be able to complete and submit them on time. Challenge yourself to confront your social and academic fears.

d. African institutions should develop an open door policy whereby exceptional students would be free to meet with them on or off office hours to discuss their academic needs. Exceptional students should take advantage of such opportunities to meet with their teachers to discuss academic or learning difficulties. 
e. Exceptional college students: when confronted with personal problems, have the courage to meet with counseling experts on campus. Be confident on your abilities and skills to make the right choices and advocate for your learning needs.

f. Universities should set up campus-wide retention programs - to look at student issues on academic and social integration of minority students and individuals with disabilities right from their first day in school. This program should be incorporated in the projects of the various Living and Learning Communities on Campus, as well as related groups. Faculty members should be encouraged to work with students with developmental and learning disabilities, and other groups to learn about their learning needs and aspirations. The administrators of the program should adopt a strategy and framework to build a student retention plan that incorporates the individual needs of their students and institution (Studentretention.org, 2005).

g. The exceptional college students should utilize test-taking tips and support from the instructors and professors.

h. African instructors should apply differentiated instruction and other teaching strategies in the classroom: Use audio-visual materials and resources in the classroom - projectors, slides, videos, films, posters, etc, and any useful teaching-learning technology tools for instructional delivery.

i. The African faculty should teach the exceptional students the APA writing styles and guide them on the research process in the first week of class.

j. Faculty should notify the different student assistance offices on campus when they discover exceptional students with disabilities. Students may be shy coming forward to present their case to them. Talk with the students and encourage them to visit the office for support. It's free!

k. Faculty should liaise with these offices especially those responsible for diversity and disabilities to provide periodic information to exceptional students on available services.

1. Faculty should invite guest speakers and professionals to the classroom to share ideas and testimonies with exceptional students.

\section{Conclusion}

The African society has a lot to learn from the special needs support services provided to her students in colleges and universities. Identifying students with developmental and learning disabilities, and supporting them in the classroom, in order to achieve success on campus is a commitment for the leadership, the instructors, professors, entire faculty and staff of every higher institution. Instructors do not always have the ability to alter course designs to accommodate students with learning and developmental disabilities, but Kelly (2010) advice that instructional designers should pay attention to course elements that might be problematic for some students. For example, students with certain visual discrimination disorders may have trouble distinguishing text from background colors. The institutions must strive to provide diverse students and individuals with different disabilities support services, and effective accommodations to ensure equal access to different college programs. The exceptional students should be willing to accept these services without shame or feeling of inferiority.

To improve college student retention, every higher institution should work further with special education faculty and staff to provide specially designed instruction, to meet the unique needs of eligible exceptional students includes the specially designed instruction conducted in the classroom, and in other settings on campus; etc. The specially designed instruction will 
assist the individuals in taking advantage of, or responding to, educational programs and opportunities on campus.

Special education provides a continuum of services in order to provide the educational needs of each eligible individual regardless of the nature or severity of educational needs. The university should also increase need-based financial aid for low-income, at-risk students; Use the campus's social and cultural activities to keep students focused; and, encourage academic advising outside the classroom (Alliance for Equity in Higher Education, 2001).

Finally, taking into consideration that not all students are alike, and based on this knowledge, the college curriculum should include differentiated instruction as an approach to teaching and learning of exceptional students. Such strategy gives students multiple options for taking in information and making sense of ideas. Differentiated instruction is a teaching theory based on the premise that instructional approaches should vary and be adapted in relation to individual and diverse students in classrooms (Tomlinson, 2001). The model of differentiated instruction requires teachers to be flexible in their approach to teaching and adjust the curriculum and presentation of information to learners rather than expecting students to modify themselves for the curriculum (Hall, Strangman, and Meyer, 2009). Many teachers and teacher educators have recently identified differentiated instruction as a method of helping more students in diverse classroom settings experience success.

This paper, therefore, advocates strongly on this process for students with learning and developmental disabilities; including an application of Universal Design for Learning (UDL), a curriculum designed approach to increase flexibility in teaching and decrease the barriers that frequently limit student access to materials and learning in classrooms (Rose \& Meyer, 2002). With all these strategies, the academic and non-academic climate for exceptional students in higher institutions, whether in America, Africa, or Nigeria, would be favorable to all. 


\section{REFERENCES}

American Association on Intellectual Development Disability AAIDD (2007). AAIDD fact sheet: Students with disabilities in schools. Retrieved March 19, 2010, from http://www.aamr.org/ehi/media/Health_Schools_Fact_Sheet_2003_202007.pdf

Allen, B.A. (1993). The student in higher education: Nontraditional student retention. The Community Services CATALYST. XXIII (2).

Alliance for Equity in Higher Education (2001). In Studentretention.org (2005).

Retention 101. Retrieved September 3, 2008, from http://www.studentretention.org/rtm101 leadership.html

Anderson, L (2006) Glossary of special education terms. Retrieved March 19, 2010, from http://www.dubuque.k12.ia.us/specialed/index.html

Bean, J.P. (1980). Dropouts and turnover: The synthesis and test of a causal model of student attrition. Research in Higher Education, 12(2), 155-187.

Berry, J.O. (2009). Lifespan perspectives on the family and disability ( $2^{\text {nd }}$ edition). Austin, Texas: Pro-ed.

Charema, J., Peresuh, M. (1996). Support Services for special educational needs: Proposed models for countries South of the Sahara. African Journal of Special Needs Education, 11 (2), 78-83. Kampala: Makarere University/UNISE.

Duquette, C (2006) Teaching students with developmental disabilities. Teaching Exceptional Children. 39 (2) 28-31.

Gladieux, L.E. \& Swail, W.S. (1998). Financial aid is not enough: Improving the odds of college success. College Board Review, 185, 16-21, 30-32.

Grol, C.E.J \& Kenosi (2000). The education of pupils with special educational needs in Africa, Looked at within the African context. ISEC Conference Proceedings. Retrieved August 31, 2010, http://www.isec2000.org.uk/abstracts/papers_g/grol_1.htm

Hall, T., Strangman, N., \& Meyer, A. (2003). Differentiated instruction and implications for UDL implementation. Wakefield, MA: National Center on Accessing the General Curriculum. Retrieved July 28, 2010 from http://www.cast.org/publications/ncac/ncac_diffinstructudl.html

Hallahan, D.P., Kauffman, J.M. (2003). Exceptional learners: Introduction to special education (ninth edition). Boston: Allyn and Bacon.

Hardman, M.L., Drew, C.J., \& Egan, M.W. (2008). Human exceptionality: School, community, and family. Boston, Houghton Mifflin Company.

Heward, W. L. (2009). Exceptional children: An introduction to special education (ninth edition). Upper Saddle River, NJ: Person-Merrill

IDEA (1990). The individual with disabilities education act. Retrieved May 27, 2009, from http://www.help4adhd.org/education/rights/idea

Ishitani, T. T. \& Stephen, L. D. (2002, June). "A Longitudinal Investigation of Dropout from College in the United States." A paper presented at the annual meeting of the Association for Institutional Research. ERIC ED473067.

Kelly, R. (2010) Teaching students with learning disabilities in the online classroom. Faculty Focus. Retrieved July 30, 2010, from http://www.facultyfocus.com/articles/onlineeducation/teaching-students-with-learning-disabilities-in-the-online-classroom/ 
Kisanji, J. (1996). The relevance of indigenous customary education principles in the formulation of special needs education policy. African Journal of Special Needs Education, 1 (2), 59-74. Kampala: Makarere University/UNISE.

Mbiti (1989). In Grol, C.E.J \& Kenosi (2000). The education of pupils with special educational needs in Africa, Looked at within the African context. ISEC Conference Proceedings. Retrieved August 31, 2010, http://www.isec2000.org.uk/abstracts/papers_g/grol_1.htm

MediZine (2010). Cerebral palsy - signs and symptoms. Retrieved March 18, 2010, from http://www.neurologychannel.com/cerebralpalsy/symptoms.shtml

Metz, G. W. (2002, October). "Challenges and Changes to Tinto's Persistence Theory." A paper presented at the annual meeting of the Mid-Western Educational Research Association. ERIC ED471529.

Metzner, B. S., \& Bean, J.P. (1987). The estimation of a conceptual model of nontraditional undergraduate student attrition. Journal of Research in Higher Education, 27, 15-38.

Mihyo, P.B. (1995). Crucial factors in teaching and learning effectiveness in Central and Southern Africa. Guest lecturer 'Lesgeven in Ontwikkelingslanden' (LIO) ('Teaching in Devloping Countries'). The Hague: Institute of Social Studies. In Grol, C.E.J \& Kenosi (2000). The education of pupils with special educational needs in Africa, Looked at within the African context. ISEC Conference Proceedings. Retrieved August 31, 2010, http://www.isec2000.org.uk/abstracts/papers_g/grol_1.htm

Mutasa, N.G. (1994). Africans contribution to science. TOJED, Tonota Journal of Education, 2 (1), 70 - 77. Tonota, Botswana: Tonota College of Education.

Noel, L., Levitz, R., \& Saluri, D. (1985). Increasing student retention. San Francisco: Jossey-Bass.

Obiozor, W.E. (2009, May). Dealing with student diversity and disabilities in the classroom: Teacher issues, challenges and support services. Review of Education, 20 (2).

Rose, D., \& Meyer, A., (2002). Teaching every student in the digital Age: Universal design for learning. Alexandria, VA: ASCD.

Smart, C (2009) Disability, society, and the individual ( $2^{\text {nd }}$ edition). Austin: Texas, Pro-ed.

Studentretention.org (2005). Retention 101. Retrieved September 3, 2008, from http://www.studentretention.org/rtn101_leadership.html

Tinto, V. (1975). Dropouts from higher education: A theoretical synthesis of recent research. A Review of Educational Research, 45(1), 89-125.

Tinto, V. (1982). Limits of theory and practice in student attrition. Journal of Higher Education, 53, 687-700.

Tinto, V. (1993). Leaving College: Rethinking the Causes and Cures of Student Attrition (2nd Edition) Chicago: University of Chicago Press.

Westling, D.L. \& Fox, L. (2004) Teaching students with severe disabilities ( $3^{\text {rd }}$ edition). Upper Saddle River:NJ, Merrill Prentice Hall.

Tomlinson, C. A., (2001). How to differentiate instruction in mixed-ability classrooms. (2nd Ed.) Alexandria, VA: ASCD.

Wylie, J. R. (2004). The influence of self-concept on non-traditional student persistence in higher education. Sydney: University of Western Sydney. 
140 Academic and Social Challenges Facing Students with Developmental and Learning Disabilities in Higher Institutions: Implications for African Colleges and Universities

\section{Web Support}

http://dsp.berkeley.edu/TeachStudentsWithDisab.html

http://www.bhsu.edu/StudentLife/Learning/DisabilityServices/tabid/162/Default.aspx

http://www.diversityweb.org/

http://www.bloomu.edu/resources/counseling.php

http://www.bloomu.edu/academic/services.php

http://www.dubuque.k12.ia.us/specialed/index.html

http://www.ed.gov/offices/OSERS/Policy/IDEA/index.html

http://www.fape.org/pubs/FAPE-13.pdf

http://www.las.iastate.edu/diversity/definition.shtml

http://www.merriam-webster.com/dictionary/DIVERSITY

AJOTE Vol. 1. No. 1, 126-140 